Article

\title{
New Labour and the Re-making of British Islam: The Case of the Radical Middle Way and the "Reclamation" of the Classical Islamic Tradition
}

\author{
Stephen H. Jones
}

Centre for the Study of Ethnicity and Citizenship, University of Bristol, 11 Priory Road, Clifton, Bristol, BS8 1TU, UK; E-Mail: stephen.h.jones@bristol.ac.uk; Tel.: +44 (0)117 3310766

Received: 22 June 2013; in revised form: 8 August 2013 / Accepted: 9 August 2013 /

Published: 4 November 2013

\begin{abstract}
This article examines the emergence of new forms of Islam in Britain between the 1990s and the present, and in particular the role played by the New Labour government (1997-2010) in encouraging new expressions of Islam. It charts the development of the Islamic tradition in Britain between the migration of mainly South Asian Muslims in the 1950s and 1960s and the Rushdie affair in the late 1980s, before outlining some of the challenges Muslims in Britain have faced transmitting Islamic traditions in a stable state to younger generations. Against the backdrop of increasing public concern about an inter-generational divide among Muslims and its supposed role in allowing radicalism to flourish, the article explores recent attempts to develop and promote forms of Islam that are "authentically British" and that challenge radical perspectives. Using the case study of the Radical Middle Way initiative, it looks into the uneasy relationship between these newer forms of Islam and the supportive New Labour administration, highlighting weaknesses in literature that focuses on the 'disciplining' of Muslims. Finally, it explains how the concept of classical Islamic tradition is utilised in creative ways not anticipated or engaged with by advocates of the "clash of civilisations" thesis.
\end{abstract}

Keywords: Islam; British Islam; immigration; Prevent; New Labour; Radical Middle Way

\section{Abbreviations}

RMW: Radical Middle Way; MCB: Muslim Council of Britain. 


\section{Introduction}

"In the realm of the political", Kwame Anthony Appiah has remarked, "theories have a habit of becoming part of what they theorize” ([1], p. x). For no recent political theory has this comment seemed more apt than Samuel Huntington's (in)famous "clash of civilizations” thesis, which is notable today not for its analytical power so much as the role it has played in shaping the West's perception of itself and of recent world events [2]. The conservative philosopher Roger Scruton has proposed that Huntington's hypothesis "has more credibility today that it had in 1993" ([3], p. vi), when it was first published in Foreign Affairs [4]. In one sense, this claim seems to be entirely wrong. The analysis that Huntington offered-in particular his suggestion that there exists today a coherent cultural entity called "Islamic civilization"- - has been repeatedly shown to be incorrect. Roy and others have demonstrated that traditional Muslim cultural formations and forms of knowledge production have been undermined by colonialism and globalization, and that many radical forms of Islam have been influenced by the militant Left [5-8]. Yet at the same time it is hard to deny Scruton has a point. Huntington's position is certainly now more widely believed, in part because his theory has had a performative effect, helping to make into a reality the very clash it predicted.

Of course, Huntington's book is not the sole cause of the widespread perception that the "Islamic world" and the "Western world" are two separate and incompatible cultural entities, and that episodes such as the 2001 attacks on the Twin Towers are best understood as the consequences of those entities colliding, like two tectonic plates; he can perhaps, as Roy has argued, be seen as a symptom as much as a cause ([5], p. 9). Yet his writing is certainly the most influential of a family of narratives about the West made by academic researchers, historians, media commentators and political figures. (In the UK, the current Secretary of State for Education, Michael Gove, takes a view not far from Huntington’s [9].) The most incendiary of these narratives, such as those by the author Bruce Bawer and the journalist Melanie Phillips, have tended to focus on Muslim immigration [10,11]. The argument in these cases has been that, as Muslims have moved in large numbers to European nations, they have gradually weakened the West's once-strong cultural foundations.

In this article I also focus on Muslim migration to Europe-and Britain specifically - though my analysis and conclusions are quite different. I offer an account of the development of the Islamic tradition in Britain, beginning with the migration of mainly South Asian Muslims in the 1950s and 1960s and focusing on new expressions of Islam that came to prominence under the New Labour government between 1997 and 2010. In doing this, my aim is not to offer a Panglossian account of the migration of Muslims to the UK in contrast to the pessimism of Huntington and his supporters. On the contrary, I highlight the significant challenges that Muslims in Britain have faced transmitting Islam in a coherent form to younger generations, as well as the profound tensions engendered by New Labour's policies toward Muslims and radicalization. However, I do focus on an organisation that presents an ironic challenge to Huntington's thesis. Central to Huntington's hypothesis is the idea that Islam and the West are culturally distinct, the latter being based on modern and secular ideas and the former being rooted in pre-Enlightenment traditions. In what follows, though, I show how new initiatives in Britain have sought to bypass imported South Asian forms of Islam, counter "youthful radicalism” and facilitate the Islamic tradition's cultural and political integration within British society precisely by “reclaiming” Islam’s traditional classical heritage. 
The analysis in this article is based upon research carried out between 2008 and 2010 which comprised a combination of 15 interviews with Muslim intellectuals, activists and religious scholars and observation of and regular participation in events held by three London-based Muslim organizations - of which one, the Radical Middle Way, is the focus here. After a first section in which I give a (necessarily brief) description of the process of Muslim migration and community formation in the UK, I describe the policy context that led to the Radical Middle Way being formed and coming to prominence, aided by government. The involvement of New Labour in a bewilderingly wide range of Muslim organisation caused, for good reason, significant controversy and has attracted significant criticism from academic researchers. While agreeing with much of this criticism, in describing the emergence of Radical Middle Way I try to point to areas of neglect, specifically the agency of Muslim intellectuals in the process of Islamic knowledge production.

\section{The Making of Islam in Britain}

Opposition of Huntington's thesis have often highlighted how, contrary to popular perception, Islam is not a new feature in the UK or, more broadly, in the West. Saeed, for example, has observed that rather than it being "a recent phenomenon mostly of the twentieth century, Islam, from its inception in the seventh century CE, has been part of the Christian West and the western psyche” ([12], p. 201). On a level, this opposition is well founded. As far back as $1641 \mathrm{CE}$ documents can be found referring to sects existing in London "with a certaine foolish beliefe of Mahomet” ([13], p. 27). There are even records of the powerful Anglo-Saxon king Offa of Mercia, who died in 796, having coins minted that had the shahada inscribed in Arabic on one side ([14], pp. 6-7). Nevertheless, it is only in the last fifty to one-hundred years that a significant minority of Muslims has settled in Britain-as well as a number of other European nation-states-permanently. In 1951 there were just 21,000 Muslims in the UK, which at the time accounted for around 0.05 per cent of the country's population ([15], p. 19). In 2001 there were 1.6 million (2.7 per cent of the total), with the figure increasing still further by the time of the 2011 Census to 2.7 million (4.8 per cent of the total).

The first large-scale migration to the UK by Muslims occurred around the time of the First World War after the fighting on the European Continent resulted in huge demand for labourers to replace soldiers abroad. Muslim seamen from the British colonies were attracted to port towns in the UK such as Cardiff, Newport and South Shields ([13], pp. 40-45 and 97). These Muslim communities, which were treated terribly following the war's end, were however small compared to those that emerged in the 1950s and 1960s following the migration of Muslim workers from (now former) British colonial territories. Migration to Britain in the mid-twentieth century was prompted by both "pull factors" (the chance to escape poverty) and "push factors" (the partitioning of India and "Africanization” policies in countries such as Kenya and Uganda). Though of diverse origins, the overwhelming majority of migrants came from what are now India, Pakistan and Bangladesh; even today, despite considerable recent diversification of the British Muslim population, 60 per cent of the UK's Muslims originate from these countries. Migration from these contexts tended to take the form of a "chain”, with initial "pioneers" from South Asia being later joined first by their immediate family, and then in many cases by members of extended kinship networks. 
According to Ansari, prior to the 1950s modernist forms of Islam were in the ascendant in the UK. The Muslim port communities in Cardiff and South Shields were fairly insubstantial and slow to establish religious institutions. The main Islamic centres were places such as Liverpool, where for a while there was a Muslim collective active in the public domain led by the prominent convert William Abdullah Quilliam, and Woking, where members of the Pan-Islamic Society ran a successful mission from the small but ornate Shah Jahan Mosque. Recognising that to make Islam appealing to a British audience it would need to be presented in a familiar form, these groups wrote in English, drew parallels with Christianity and challenged traditional Islamic position regarding the seclusion of women and punishments for "apostates" ([13], pp. 130-33). Members of the Pan-Islamic Society in London also distilled the hadith volumes into short books with the aim of correcting misconceptions about the faith (see for example [17]).

Most of the migrants that journeyed to the UK from South Asia in the 1960s came, as Lewis observes, from "rural contexts where Islam was part of the rhythm of life" ([15], p. xvii). They were thus unfamiliar with this modernist movement. Upon migrating many had little intention of making the UK their permanent home, but as the dream of one day returning to their country of birth began to fade they started to construct institutions and communities that would enable them to practice the Islamic tradition with which they were familiar as best they could and help them preserve that tradition for future generations. Efforts were made to import distinctive Islamic traditions into the UK (sometimes literally, with religious leaders being brought in from overseas) and slowly from the 1960s through into the 1970s and '80s these forms of Islam became dominant. Mosques and madrasas were set up which inevitably reflected the particular linguistic and doctrinal character of their founders ([13], pp. 342-43; [18], pp. 56-58). Indeed, the creation of these institutions following migration led to Muslim migrants separating into groups, as Ansari explains:

Segregation [between different Muslim groups followed chain migration], and previously ethnically mixed Muslim communities increasingly fragmented according to village-kinship, tribal, ethnic and sectarian affiliation. Indians, Yemenis and Turkish Cypriots who had lived together in boarding houses during and after the Second World War, sharing more or less the same religious facilities, gradually separated to form ethnic settlements that then established their own distinct institutions. Mosques and religious schools also reflected this process of segmentation, and imported religious functionaries reminded Muslims of their traditional values and reinforced conformity to embedded practices ([13], p. 343).

These new communities, in which religious, ethnic and cultural identification were all tied into one another, were semi-autonomous, often providing support networks for their members. They remained aloof from British society to an extent (for details see [13], p. 213), making few demands and entering into political debates rarely. When Muslims did enter into political debates it was generally to secure accommodations from government, most successfully in education. During the 1970s numerous efforts were made to change education policy, primarily to facilitate the smooth transition of Islamic traditions. For many, this meant protecting younger Muslims from "undesirable” influences in British society, with requests being made for the expansion of same-sex schools, or schools with a specific confessional ethos (see [13], pp. 309-17).

Because the ancestry of the British Muslim population is extremely complicated it is impossibly difficult to describe all the different varieties of Islam that emerged in the UK following the post-World 
War II period of migration. There are, however, two strands of the Islamic tradition that have been particularly influential due to the fact that they predominate in the South Asian context: the Barelwi and Deobandi movements. Both of these emerged in the 1850s during the period of British colonial rule in India. The former is the largest in Britain, followed by the latter. Barelwis follow a form of Sufi-inspired devotional Islam which was consolidated in Bareilly in northern India, after which the tradition is named. Cities such as Bradford have large Barelwi communities, with fifteen of the thirty-four mosques that were based there during the late 1980s being linked to the tradition ([13], pp. 346-47; [19], pp. 118-19). The Deobandi movement is historically based on the teachings of the Dar al-Ulum Deoband in India, which was founded in the 1860 s by a group of 'ulama who were committed to preserving Islamic scholarship and learning at a time when the influence of the British and Christian elite was growing ([18], pp. 36-38; [20], p. 183). This movement has tended to subvert classical scholarship by insisting that Islamic norms must be linked to scriptural proofs found in the Qur'an and collections of hadith ([13], p. 347; [20], p. 188). Although literalistic in some respects, in contrast to politicized Islamic movements such as the Jamaat-i-Islami, the Deobandi movement has generally been apolitical or even anti-political ([15], pp. 93-103; [20], pp. 183-94). In the UK this anti-political trend has become predominant, partly due to the outreach movement Tablighi Jama'at, which has its European headquarters in Dewsbury. The Deobandi movement is particularly strong in Leicester and Birmingham, and has been successful in establishing a network of dar al-ulums across the UK, with a main centre of learning located in Bury ([15], p. 89; [20], p. 187).

\section{A Crisis in Transmission?}

Muslim migrants to Britain have faced considerable barriers when they have tried to establish community infrastructure — such as, for example, local authorities needlessly obstructing planning applications for religious buildings [21]. Their success in doing so is therefore impressive for a range of reasons - even if, as this I will discuss shortly, the existence of semi-autonomous ethno-religious communities in the UK has recently been singled out by policy-makers as a problem. However, what has become apparent in recent decades has been the profound difficulties the Muslim groups that emerged in the UK in the 1970s have had maintaining their interpretations of Islam in a stable state over time. Lewis for example has observed that "many parents and religious leaders, imported into Britain's mosques from the [South Asian] religio-cultural world, are often at a loss to help their children answer questions about Islam posed by school friends, teachers or youth workers.” They are, he suggests, unable to provide Islamic teachings that "can connect with [the] lived experience [of] British Muslims whose first language is English” ([15], p. xvii).

An insight into these problems can be gained by looking at the content of the curriculum taught in some of the Deobandi dar al-ulums in Britain. Research into these institutions has indicated that, at least until relatively recently, they worked from an attenuated version of the religious education syllabus developed in Lucknow known as dars-i-nizami, which was itself inherited from eighteenth-century Farangi Mahall scholars. The educational system developed by these earlier scholars was rich, covering elements of Persian literature, logic and mathematics. Yet for reasons outlined earlier, these elements were marginalized by the Deobandis in favour of renewed emphasis on the Qur' an and hadith and the preservation of the core "Islamic sciences" (that is, methods of exegesis and the formulation of 
legal opinions) ([18], pp. 36-38). This is reflected in the British institutions, where the curriculum has focused on the study of textual commentaries, usually on matters of law and hadith. Students are required to translate the Qur'an and hadith collections from Arabic into Urdu, and are asked to show an awareness of key texts and commentaries. They may be encouraged to ask questions of clarification, but not of substance. Teaching itself is often in Urdu, although with a minimal English curriculum taught in the afternoon in order to conform to English law ([15], p. 100; [20], p. 188; [22], pp. 65-66).

The problem with this that various researchers — and indeed some Muslim religious leaders (see the quotes in [23], pp. 15-16) — have identified is that it lacks much by way of a relationship to the distinct history and character of the UK. The centres produce new religious leaders yet, as Gilliat-Ray has noted, "what is striking is the absence of subjects that might help graduates engage with British Muslim youth, and the society in which they are based" ([22], p. 66). The situation in mosques appears to be similar. One study, which surveyed five-hundred of the UK's fifteen-hundred or so mosques, indicated that 44 per cent of mosques do not include English in their Friday sermons, preferring instead Punjabi, Bengali or Guajarati ([23], p. 14). Figures from the British Foreign Office also indicate that large numbers of imams are still imported to serve in places of worship ([15], p. 94), meaning that perhaps 90 percent receive their religious formation abroad ([23], p. 14). Women appear also to be for the most part excluded from these places of worship: just 46 per cent have prayer facilities for women, and rarely can women speak with an imam ([23], pp. 19-20).

On its own, it is unlikely that this issue would have attracted the interest of policy-makers and political commentators. However, since the Rushdie affair in the late 1980s, and particularly since the turn of the century, the isolation of Muslim communities and the tension between younger from older generations has been singled out as one of the causes of a number of violent episodes. For example, efforts to maintain stable Muslim communities came to be identified as one of the major barriers to "community cohesion”, which in turn was singled out as a major contributing factor to a series of riots in Oldham, Burnley and Bradford in the North of England in 2001 [24]. This led to renewed emphasis in UK social policy on the need to foster mixing between religious groups and identification with the British nation (as well as, critics have persuasively argued, less emphasis being placed upon economic deprivation and prejudice against minorities [25]).

More significantly, challenges in transmitting Islamic traditions to the younger generation have come to be linked with events such as the London bombings of July 2005. With young, Englishspeaking Muslim men and women who hold their religious faith to be of fundamental importance being, supposedly, badly served the older, foreign-born individuals who retain control over the majority of mosques, young Muslim have turned to other outlets for their religious guidance ([26], pp. 124-25). Concern has arisen because, in a few cases, young Muslims' frustration with their parents' faith has resulted in a search that leads ultimately to the adoption of a literalistic and intolerant form of Islam ([5], pp. 257-65). For some, radical parties have, as one former member of the revivalist movement Hizb ut-Tahrir has observes, "fill[ed] a void for the young intellectually frustrated youth who had been told that Islam is the truth and they must pray and fast by people who couldn't explain why” ([15], p. 138). The account of Hassan Saleemi, another ex-Hizb ut-Tahrir member now working on the Islam Channel, is illustrative of this tendency: 
At eighteen - with the unearthing of Public Enemy, who were talking about "fight the power," imperialism and slavery - I was unhappy with Pakistani Asian culture, I was unhappy with British culture and I was not happy with the sectarianism in my local mosque. I felt alienated from Muslims and I had some grounding in colonialism. I had a history GCSE and was doing a history A-level as well, so I knew a bit about colonialism.... And [then] there was a tall white guy outside my mosque [who was a representative of Hizb ut-Tahrir] talking about Bosnia and Kashmir, and giving out leaflets, and the fact that he was white struck me. I attended the talk, and you could say the rest is history [27].

The emergence of such viewpoints and their apparent link to movements that have inspired militant protest and violence led to the widespread problematization of what has been termed the "subculture" of mosques and madrassahs. Between 2005 and 2010 in particular it became common to see views such as the following from Paul Goodman, the former Conservative Shadow Minister for Communities and Local Government (who withdrew from British politics following the 2010 general election), expressed among policy-makers:

The consensus about how to combat violent extremism can be summed up in three words: reform the mosques. British mosques and madrassahs - the argument runs - are dominated by elderly men from abroad who don't speak English and have limited means of communication with the younger generation. This leaves young British Muslims vulnerable to exploitative English-speaking al-Qa'eda operatives. The solution to this seems obvious: open up the mosques. Bring in young, English-speaking people to run them. Sweep away the old-fashioned assumptions, and empower Muslim women. Above all, monitor the masjids and madrassahs. Inspect them, regulate them, control them and subject them to the blizzard of best practice and quality standards guidance that's done so much for local government [28].

\section{New Labour and the "Remaking" of Islam in Britain}

Goodman above does not, in fact, just express a widely held opinion, but provides a summary of what, in the wake of the 2005 London bombings, became official policy in the New Labour government. The Labour Party has traditionally attracted a disproportionate number of the votes of ethnic minorities in Britain, and has a long and complex history of forming partnerships with ethnic minority associations. Upon coming to power in 1997 New Labour formed a close relationship with the recently formed Muslim Council of Britain (MCB), a group that had been developed ostensibly in order to allow Muslims to speak, politically, with "one voice”. This relationship remained close for a little under a decade, and was marked by efforts to secure various gains for Muslims in Britain including, inter alia, strengthened religious discrimination legislation and the addition of a question about religious identity in the decennial national census. Following the London bombings, however, this relationship broke down and the character of New Labour's engagement altered.

Firstly, under considerable pressure from a rapidly proliferating array of Muslim representative bodies and a growing body of critics on both sides of the political spectrum, who viewed the MCB as dominated by conservative male elders (and in some cases dangerous “Islamists”), New Labour sought out new partners such as Quilliam and the Sufi Muslim Council (for details see [29,30]). Secondly, under pressure to develop a response to the extremist perspectives that the London bombers espoused, the party started to adopt a more direct (or even invasive) approach to Islam in Britain. Islamic 
knowledge was not something that often entered into the political arena in the 1990s and early 2000s when New Labour engaged with the MCB regularly. Indeed, the MCB has never sought to represent Islam but rather "British citizens with an Islamic heritage", implying the full range of Muslims, from the devoutly religious to those who do not identify with any theological vision [31]. Yet in this new environment religious knowledge became an issue, with the UK government endeavouring to influence the production and dissemination of Islamic knowledge.

This shift happened following the development by New Labour of the "Prevent" (known also as "Preventing Violent Extremism”, or PVE) agenda [32,33]. Announced in February 2007 by Ruth Kelly, the then Secretary for Communities and Local Government, the agenda's conscious aim was to develop a "British version of Islam" ([34], p. 11). This mirrored the remarks of Nicolas Sarkozy in France, who has favoured a more "corporatist" approach to state engagement with Muslims ([35], p. 182) and who has stated on various occasions that what he would like to see is an "Islam de France" rather than "en France" ([36], p. 71). At the time of its launch, five-million pounds were dedicated to Prevent, money to be spent training foreign-born imams and, Kelly said, inducing a "step-change in the role of madrasahs in teaching about citizenship” ([34], p. 11).

From there, the strategy progressed rapidly: in 2008/2009 one-hundred and forty million pounds were earmarked for Prevent-related community initiatives ([37], p. 10). The funding of Muslim groups increased and at the same time broadened. Prevent money was offered to a bewildering array of community initiatives, some very different to the others. The Preventing Violent Extremism Community Leadership Fund funded organizations such as, in 2007/2008: the Muslim Youth Helpline (£35,000); Khayaal Theatre Company (£38,450); the Muslim Youth Development Partnership (£40,000); the Sufi Muslim Council (£58,500); the Luqman Institute of Education and Development $(£ 30,000)$; and the Fatima Women’s Network $(£ 10,000)$. At the same time, pots like the Community Leadership Fund were made available to groups such as the British Muslim Forum, British Muslims for Secular Democracy, and the Mosques and Imams National Advisory Board (MINAB), which received just over $£ 75,000$. Money was also targeted at Muslim women’s projects such as the Muslim Women's Network with the aim of “enabling [women's] voices to be heard and empowering them to engage with Muslims at risk of being targeted by violent extremists” [38].

At a rhetorical level and in decisions about the allocation of public funding, the interpretation of Islam became more salient. Ministers such as Kelly began to quote Muslim intellectuals such as Tariq Ramadan, suggesting that they offer a vision for a fully integrated British Islam [34]. Islamic Studies was named by the Labour Government as a "strategically important subject” in 2007 ([39], p. 4; [40]). This was also supported by government-sponsored university-based initiatives such as "Contextualising Islam in Britain”, a project funded by the Department for Communities and Local Government and based at the University of Cambridge whose main aim was to allow Muslims to come together to discuss what it means to faithfully live as a Muslim in modern Britain. This project did not shy away from theology, covering Islamic conceptions of justice, the objectives (maqasid) of Islamic law, and the nature of divine sovereignty. Funds were made available to train imams [42-44], and partnerships between Islamic centres of higher learning and universities were considered [45]. Finally, New Labour funded organizations involved in the dissemination of Islamic knowledge through "tours" of religious scholars and through on-line videos and podcasts. One of these organizations I shall concentrate on in the remaining sections: The Radical Middle Way. 


\section{Reclaiming the Centre Ground: The Case of Radical Middle Way}

The Radical Middle Way (RMW) is an initiative that grew out of the Muslim magazine Q-News, which was established in the early 1990s and continued until 2006. In its heyday, Q-News had a readership of 60,000 people per month, comprising mainly second and third generation British-born Muslims as well as non-Muslim religious educators and policymakers. Justly regarded by commentators as an energetic and innovative publication ([14], p. 236-38), Q-News tended to treat established Muslim representative bodies with a degree of scepticism; the magazine characterised the MCB at one point as "lassi Islamists" (a South Asian variant on the derogatory characterization of leftist groups as “champagne socialists” [31]). As Fozia Bora, one of the magazine's contributing editors, notes, "Q-News was jaded with all these institutions and made it clear that these organizations were not representative in any way because they didn’t represent” (interview, 6 March 2012). Notably, though, the magazine was respectful of Islamic scholarship, and included a regular series on "questions and answers about Islam” by prominent religious scholar [46].

In its early days, Q-News struggled to attract the attention and support of public bodies. In fact, this lack of support was the reason behind the magazine's name. According to the founding editor of Q-News and RMW's founder, Fuad Nahdi, faith-based publications in the early 1990s were not able to attract advertising revenue from public equalities bodies, which tended to focus on relations between groups defined by "race” and ethnicity. Q-News did not wish to align itself with any ethnic group but needed this advertising revenue to survive, and so a "non-religious” name was adopted ([29], p. 31). By the time the magazine published its final issue in 2006 after RMW was launched, this situation had changed entirely. Public funding for religious groups, especially Muslim groups, was readily available for cohesion, capacity building and preventing extremism projects. Thus in the second half of the 2000s RMW received considerable public support-for example, £350,000 in 2009 from the Department of Communities and Local Government [38].

RMW has thus been since its inception firmly entangled in New Labour's efforts to re-make the Islamic tradition in Britain, even if it has never been funded by Prevent monies directly. It is important, though, to treat this issue with care. Academic analysis has tended to see the policies of the UK government toward British Muslims as characterized by a range of strategies and policy mechanisms designed to contain dissent, discipline (or "securitize") Muslim communities and "domesticate" Islam [37,47,48]. Neo-Foucauldian writings on governmentality (see [49]) have had considerable influence [50]. The focus in research has, in general, been on the discourses and conduct of government: for example, New Labour's tendency to frame Muslims as "good" and "bad" or "moderate" and "extremist" [48,51]; or the characterisation of Muslim women as "wives and mothers" capable of mollifying "combative masculine” forms of Islam [52]. This body of criticism has made a number of forceful points. Among other things, it has drawn attention to the way in which New Labour effectively placed the burden of the 7/7 bombings on contemporary Islam and British Muslim communities, rather than addressing any deeper sociological or political tensions. It has highlighted how New Labour policy was developed such a way that reinforced regressive gender roles, even as New Labour sought to open up mosques to Muslim women [52].

Nevertheless, this overriding focus on the discourses and conduct of government has left relatively little room to examine the production of Islamic knowledge. As Sunier explains: 
The emphasis on governance, national identity politics, and integration and security in the study of Islam in Europe ... often conceals and ignores certain issues and trends among Muslims in Europe that are very important. This has produced a paradoxical situation. Whereas Islam has become the common denominator for a wide range of phenomena, attitudes and developments, as fields of research, religious practices and the production of religious knowledge among Muslims have suffered from programmatic concealment and downright neglect [53].

A side-effect of this has been a tendency to neglect of the practical uses of Prevent and other funding, which in turn has led to the creative agency of individuals involved in project delivery being downplayed. As the disciplinary role of the state is emphasised, critics can often imply that the forms of Islam that find favour with government are state creations certified by government and "imposed" on Muslims from above through various policy programs. The case of RMW indicates, however, that the situation is more complex than this. Certainly, the change from the early days of Q-News to the launch of RMW in 2006 was profound, and involved an at times uncomfortable move among the staff of the two organizations from being "poachers" to being "gamekeepers". In the period during which RMW received large amounts of public funding RMW had to make, as Abdul-Rehman Malik, who works for RMW and who wrote for Q-News, acknowledges, "a big trade-off in terms of fighting for credibility and fighting for the money to operate” (interview, 26 August 2008). One of RMW's most prominent speakers observes that by taking public funding organisations such as RMW risk being "generically discredited" because "everyone assumes that point of view is being pushed for political reasons by the same politicians that support Israel and smashed up Iraq” (interview, 27 August 2008). Yet there is continuity in the positions argued by the people behind both the organizations. There is a distinctive approach and a reliance upon specific forms of scholarship that has remained consistent and that has built up a following over more than two decades.

Throughout, Q-News and RMW have drawn on a distinctive range of Islamic scholars from the UK (such as Abdal-Hakim Murad, Zaki Badawi and Hasan Le Gai Eaton), Muslim-majority countries (Abdallah Bin Bayyah from Mauritania and Ali Gomaa from Egypt) and the US and Canada (Suhaib Webb, Hamza Yusuf and Ingrid Mattson). Scholars from the US have been particularly notable. (The links between British and American Islam have not been subject to much scrutiny: it is an area in need of further research.) All of these individuals have one thing in common: they have scholarly qualifications - usually from both Islamic seminaries and conventional universities (indeed many are religious teachers and university professors)_but they are not “conventional” mosque leaders. They differ from dominant South Asian forms of Islam and are consciously opposed to Salafism of the kind that influences the youthful revivalisms described earlier in this chapter. This dual break was crucial to $Q$-News's success and is even more central to RMW.

Between 2006 and 2010 RMW's activities were concentrated on "tours” of scholars around the UK, London, Birmingham and Bradford being a particular focus. These were highly popular: in February 2003 the American 'alim Hamza Yusuf, founder of the Zaytuna Institute in California, drew an audience of between four- and five-thousand when he arrived in England to speak at a mosque in Bradford - a huge audience given that the talk took place in a city of around 300,000 people, of whom around 16.1 per cent are Muslim [15]. Consistently across these tours radical revivalism is treated with 
scepticism. On occasion, it is treated to a form of sociological examination, as in the following excerpt from a talk given in London by the charismatic American preacher Suhaib Webb:

[We need to understand], in the spirit of Ibn Khaldun, ${ }^{1}$ the sociological reality of the Western Muslim. We come from the DMX madhhab. ${ }^{2}$ We come from Star Wars. We come from professional wrestling. We come from Bruce Lee. We come from a misogynistic reality that dominates women, in hip hop music.... And you give this religion to someone who comes from that background and what type of mentality is he going to have to his fellow brothers and sisters? He is Luke and Obi-Wan vs. Darth Vader.... [T] he social constructs that we live [with] in the West are those of domination. We seek to dominate others - and then we're given a group mentality that transforms itself into attacking fellow Muslims.... [S]o Hulk Hogan and Andre the Giant now know about Ibn Taymiyya and Ibn Arabi, ${ }^{3}$ and they're going to take it to the masjid and battle each other! Go on-line and look at our forums about how we talk about scholars and individuals, how we talk about each other - the hatred, the spite. Why? DMX mentality [54].

More regularly, though, opposition to such forms of Islam is rooted in emphasis on the authoritative role of Islamic traditions of scholarship. Its outlook has been heavily influenced by, in Malik's words, "Western Muslims who [are] reclaiming the classical tradition” (interview, 26 August 2008). The following two excerpts are among the clearest examples of this. The first comes from a talk on extremism by the American Muslim Umar Abd Allah, who has taught in Jeddah and the United States. This talk was delivered at Birmingham Central Mosque in 2006:

Extremism often expresses itself in a personal quest for immediately accessible knowledge.... And often this is in defiance of authority; I mean by that in defiance of traditional authority, of the schools, the tradition, the teachers. As one of the great scholars that I used to know in Morocco used to say, who was a great muhaddith, he would say: "I studied hadith all my life; I studied Islam all my life, and a young man who doesn't even pray goes into the movie theatre, comes out, buys a pamphlet, and the next day he's calling me a kaffir".... The religiosity of extremism is often based upon personal experience, and not legacy [55].

The second comes from the British Muslim convert Abdal-Hakim Murad (a.k.a. Tim Winter). Murad is one of British Islam's most prominent intellectuals. He teaches at Cambridge University, though he is also an imam as well as one of the founders of the Cambridge Muslim College, a recently established educational institution that seeks to enable religiously trained imams to engage successfully with British society. The following was delivered at a talk in London in 2005:

[The Islamic tradition is in need of] renewal, every Muslim accepts that. The religion has become old, doddery, cantankerous. The sole source of renewal is that which was good for the earliest generations of this Umma; that's established, nobody will deny it. But the difference between 'alim the and the amateur is that the 'alim says we'll deal with the tree as it is, we keep it going; alhamdulillah we still have it and over the years it has acquired a certain magnificence, that in itself has the right to be respected and enjoyed. The amateur scholar says, "No, the best thing is to cut it down and we'll be back in 1453 again, or indeed back at

1 Ibn Khaldun (1332-1406) was a philosopher sometimes characterized as a sociologist avant la lettre on account of his work mapping the character of different societies.

2 DMX is a popular US-based hip-hop artist.

3 Ibn Taymiyya (1263-1328) was a significant Sunni Muslim jurist and Ibn Arabi (1165-1240) was a theologian and philosopher influential in Sufism. 
the time of the Hijra, in the time of the Prophet, sallallahu alaihi wa sallam”. This is really what is at stake. We have a tree that is more intact than the trees of the other [major religious traditions]; but we have, given the nature of the age, an increasing proliferation of people who misunderstand it, who are not grateful for it, who can't see its current beauty, who have not trained with those who have been looking after it, and think that the solution is actually to cut it down. The great calamity in our age is not that Islam needs a Reformation or that we need a liberal Islam; the great calamity is that we are not being true to our own traditions of scholarship [56].

The normative emphasis placed upon authority in these passages is easily misinterpreted. It is important to remember that RMW is not a traditional institution at which students spend years studying the intricacies of fiqh. For the most part, its activities remain distinct from mosques and formal educational institutions, and events are usually held in secular spaces. The Internet is a central medium for the dissemination of information, and browsers can dip into and out of the different sermons and teachings that are provided. Moreover, alongside these scholar-focused events RMW has organized events involving music and forms of cultural expression that are more conventionally associated with the 16 to 30 year olds who make up the majority of the audience at most of RMW's meetings. Rather than simply stressing the importance of maintaining existing tradition, this emphasis on classical scholarship and a legacy that stretches back hundreds of years becomes a way of reworking the Islamic tradition within the context of contemporary Britain.

It is important to note, too, that the scholars and preachers involved in RMW stress the possibility, indeed the necessity, of embedding Islam in British traditions and cultural forms. This indeed is the main point on which the RMW's founders and New Labour agreed. Murad for example, stresses the point that classical fiqh traditionally recognised local laws and customs ('urf) if they did not directly conflict with Islamic teachings. "Islam, as a universal religion, in fact as the only legitimately universal religion,” Murad notes, “also makes room for the particularities of the peoples who come into it” [57]. The Cambridge-based imam has even edited a book of Muslim songs of the British Isles, taking traditional British folk songs and fusing them with Islamic themes [58]. Classical tradition and Westernization are portrayed as proceeding hand-in-hand.

The fact that RMW is not a traditional Islamic educational institution makes it difficult to evaluate its impact on the behaviour and thinking of British Muslims, and ultimately its success in reconnecting the Islamic tradition with British cultural forms. The organisation produces what Roy ([5], p. 7) terms "floating discourses"- one-off sermons and podcasts whose physical effects are difficult to trace. We do know that during the period it received large amounts of funding the organisation was very popular, with an estimated 70,000 people attending the organisation's events prior to 2009 [60], but it is hard to be clear about RMW's direct role in the creation of new institutions or community movements. Whatever its immediate impact, RMW's capacity was reduced substantially following a 2010 general election, which saw New Labour replaced by a Liberal-Conservative coalition. RMW had a number of supporters in Parliament and, unlike the MCB, maintained cordial relations with government. While its support by the state prompted some criticism, its patronage was never as controversial among British Muslims as that of Quilliam, a 'counter-extremism think tank' openly supportive of Prevent. Yet despite this RMW's funding fell victim to the coalition's austerity programme, with Conservatives in 
particular arguing that as the organisation did not engage consistently with the problem of militant religious extremism its continued funding could not be justified.

Nevertheless, when considering both the impact of RMW and its rise and fall in the eyes of government it is helpful to keep in mind that it, as I have been arguing, forms one part of a wider network of organisations and individuals whose history can be traced back to at least the 1990s and that remain active in Muslim civil society. Its aim of reworking Islamic scholarship is shared by a number of other British Muslim educational organisations (some of which have direct links to RMW), such as Maslaha, the An-Nisa Society the Cambridge Muslim College, the Muslim College and Campusalam. These groups together are illustrative of a longer term civil society response to sociological changes within the British Muslim population that is still being gradually worked out and that, while certainly affected by government policy, is not reducible to it.

\section{Conclusions}

In this article I have, by focusing on transitions and processes of contestation and change within Islam in Britain, presented a picture that contrasts sharply with the characterisation of Islam as a coherent, undifferentiated cultural formation. With these processes of contestation and change taken into account, it becomes much harder to argue coherently-as Huntington and his more uncompromising followers such as Bawer and Phillips do-that there exists a fundamental cultural tension between Western and Islamic cultures, and next to impossible to see events such as the London bombings in 2005 as the product of a profound cultural divide. More specifically, I have sought to show how, in response to a complex combination of tension across generations, New Labour policy and the distinct social makeup of the UK, Muslim organisations and intellectuals have begun to reach back into and "reclaim" the Islamic past to address challenges of the present. This effort has not been widely discussed-in part, I have suggested, because of a lack of scholarly focus on Islamic knowledge, but also because fails to fit the preconception common to Huntington and his followers as well as policymakers in the UK that the successful acculturation of Islam in Britain requires simply the liberalization of the tradition to "bring it up to speed" with modernity.

It would nevertheless be misleading to suggest that there are no points of tension within the Islamic tradition in Britain or between the Islamic tradition and wider British society. Government policy toward Muslims has responded to some genuine challenges, including a difficulty translating Islamic traditions and movements into the UK and a resulting tension between Muslim generations. The extent to which these difficulties have encouraged extreme interpretations of Islam is debatable; often overlooked in debates are factors such as foreign policy and poverty (young Muslims in the UK are more than twice as likely to be unemployed than the national average [60]). Nevertheless, they cannot be entirely discounted. Moreover, efforts at renewal also have internal tensions. RMW's emphasis on scholarly authority and the classical tradition has allowed it to bypass established centres of religious transmission and challenge literalism, but presently there is not yet the institutional capacity to creatively reinterpret this tradition and authoritatively address social questions about political rights, social relations, personal morality and the appropriate relation between these. As I have noted, some new Islamic educational institutions have emerged in recent years with something like this aim, but these are at best initial steps in what could be a long process. 
There have also been tensions and difficulties within UK government policy toward Muslims. In this article I have offered an account of Islam and public policy in Britain that differs in some respects from accounts stressing the "domestication" of Islam and the "securitization" of Muslim communities. Nevertheless, it has been clear that, across successive governments, policy has been fixated on security, to the point where almost all government support given to Muslims has been justified by making reference to the need to counter extremism. New Labour were certainly guilty of this but it is perhaps the decision by the coalition to cease funding RMW in part because it addressed broader concerns than terrorism that perhaps provides the most vivid illustration. There has not been space in this article to fully consider this issue, but it may be that reducing the emphasis on combating extremism might, paradoxically, allow Islam in Britain to develop on its own terms, eventually even becoming stable, confident and capable of opposing extremism more effectively.

\section{Acknowledgements}

The research on which this article is based was made possible by a studentship provided by the Economic and Social Research Council (pta-031-2005-00210). Although based on research carried out between 2008 and 2010, this article has also benefitted considerably from conversations with colleagues at the University of Bristol with whom I worked on the "Muslim Participation in Contemporary Governance” project between 2011 and 2012. I am grateful in particular to Therese O’Toole, Daniel Nilsson DeHanas, Tariq Modood and Nasar Meer. Of course, I bear sole responsibility for the argument and any errors.

\section{Conflict of Interest}

The author declares no conflict of interest.

\section{References and Notes}

1. Appiah, Kwame Anthony. The Ethics of Identity. Princeton, NJ: Princeton University Press, 2005.

2. Huntington, Samuel P. The Clash of Civilizations: And the Remaking of World Order. London: Simon \& Schuster, 1997.

3. Scruton, Roger. The West and the Rest: Globalisation and the Terrorist Threat. London: Continuum, 2002.

4. Huntington, Samuel P. “The clash of civilizations?” Foreign Affairs, Summer 1993, pp. $22-49$.

5. Roy, Olivier. Globalised Islam: The Search for a New Ummah. London: Hurst \& Co., 2004.

6. Mandaville, Peter. Transnational Muslim Politics: Reimagining the Umma. London: Routledge, 2001.

7. Gray, John. Al-Qaeda and What It Means to Be Modern. London: Faber \& Faber, 2003.

8. Beck, Ulrich. Cosmopolitan Vision. Cambridge: Polity, 2006.

9. Gove, Michael. Celsius 7/7. London: Weidenfield and Nicolson, 2006.

10. Bawer, Bruce. While Europe Slept: How Radical Islam Is Destroying the West from Within. New York: Doubleday, 2006.

11. Phillips, Melanie. Londonistan. New York: Encounter Books, 2007. 
12. Saeed, Abdullah. "Muslims in the West and their attitudes to full participation in Western societies: some reflections." In Secularism, Religion and Multicultural Citizenship. Edited by Geoffrey Brahm Levey and Tariq Modood. Cambridge: Cambridge University Press, 2009, pp. 200-15.

13. Ansari, Humayun. The Infidel Within: Muslims in Britain Since 1800. London: Hurst \& Co., 2004.

14. Gilliat-Ray, Sophie. Muslims in Britain: An Introduction. Cambridge: Cambridge University Press, 2010.

15. Lewis, Philip. Young, British and Muslim. London: Continuum, 2007.

16. Office for National Statistics. Religion in England and Wales 2011. London: Office for National Statistics, 2012.

17. Abdullah al-Mamun al-, Suhrawardy. The Sayings of Muhammad. New York: Arno, 1980.

18. Lewis, Philip. Islamic Britain. London: I. B. Tauris, 2002.

19. Bhatt, Chetan. Liberation and Purity: Race, New Religious Movements and the Ethics of Postmodernity. London: Routledge, 1997.

20. Birt, Jonathan. "Locating the British Imam: The Deobandi Ulama between Contested Authority and Public Policy Post-9/11.” In European Muslims and the Secular State. Edited by Jocelyne Cesari and Seán McLoughlin. Aldershot: Ashgate, 2005, pp. 183-96.

21. Gale, Richard, and Simon Naylor. "Religion, planning and the city: the spatial politics of ethnic minority expression in British cities and towns.” Ethnicities 2, no. 3 (2002): 387-409.

22. Gilliat-Ray, Sophie. "Educating the 'ulama: centres of Islamic religious training in Britain.” Islam and Christian-Muslim Relations 17, no. 1 (2006): 55-76.

23. Dyke, Anya Hart. Mosques Made in Britain. London: Quilliam Foundation, 2009.

24. Cantle, Ted. Community Cohesion: A Report of the Independent Review Team. London: Home Office, 2001.

25. Yuval-Davis, Nira, Floya Anthias, and Eleonore Kofman. "Secure borders and safe haven and the gendered politics of belonging: beyond social cohesion.” Ethnic and Racial Studies 28, no. 3 (2005): 513-35.

26. Parekh, Bhikhu. A New Politics of Identity: Political Principles for an Interdependent World. New York: Palgrave Macmillan, 2008.

27. Saleemi, Hassan. "Islamic activism in the UK: then and now." Presented at City Circle, London, 29 June 2007.

28. Goodman, Paul. "MINAB's mosques may not be so moderate." Daily Telegraph, 30 November 2007. http://www.telegraph.co.uk/comment/3644400/MINABs-mosques-may-notbe-so-moderate.html.

29. O’Toole, Therese, Daniel Nilsson DeHanas, Tariq Modood, Nasar Meer and Stephen H. Jones. Taking Part: Muslim Participation in Contemporary Governance. Bristol: University of Bristol, 2013.

30. Birt, Jonathan. "Lobbying and marching: British Muslims and the state." In Muslim Britain: Communities Under Pressure. Edited by Tahir Abbas. London: Zed Books, 2005, pp. 92-106. 
31. McLoughlin, Seán. "The state, new Muslim leaderships and Islam as a resource for public engagement in Britain.” In European Muslims and the Secular State. Edited by Jocelyne Cesari and Seán McLoughlin. Aldershot: Ashgate, 2005, pp. 55-70.

32. Department for Communities and Local Government. Preventing Violent Extremism: Winning Hearts and Minds. Wetherby: Communities and Local Government Publications, 2007.

33. Thomas, Paul. "Failed and Friendless: The UK's 'Preventing Violent Extremism' Programme.” The British Journal of Politics \& International Relations 12, no. 3 (2010): 442-58.

34. Kelly, Ruth. “Time for a British Version of Islam...” New Statesman, 9 April 2007, p. 11.

35. Modood, Tariq. "Muslims, religious equality and secularism." In Secularism, Religion and Multicultural Citizenship. Edited by Geoffrey Brahm Levey and Tariq Modood. Cambridge: Cambridge University Press, 2009, pp. 164-85.

36. Caeiro, Alexandre. "Religious authorities or political actors? The Muslim leaders of the French representative body of Islam.” In European Muslims and the Secular State. Edited by Jocelyne Cesari and Seán McLoughlin. Aldershot: Ashgate, 2005, pp. 71-84.

37. Kundnani, Arun. Spooked: How Not To Prevent Violent Extremism. London: Institute of Race Relations, 2009.

38. Hansard. "House of Commons daily debates.” United Kingdom Parliament, 26 February 2009. Available online: http://www.publications.parliament.uk/pa/cm200809/cmhansrd/cm090226/text/ 90226w0033.htm (accessed on 12 March 2010).

39. Higher Education Funding Council for England. Islamic Studies: Trends and Profiles. London: HEFCE, 2008.

40. Siddiqui, Ataullah. Islam at Universities in England: Meeting the Needs and Investing in the Future. Leicester: The Markfield Institute, 2007.

41. Suleiman, Yasir. Contextualising Islam in Britain: Exploratory Perspectives. Cambridge: Centre of Islamic Studies, 2009.

42. Paton, Rob, Haider Ali, and Lee Taylor. "Government support for faith-based organizations: the case of a development programme for faith leaders.” Public Money \& Management 29, no. 6 (2009): 363-70.

43. Yazbeck Haddad, Yvonne, and Michael J. Balz. "Taming the imams: European governments and Islamic preachers since 9/11.” Islam and Christian-Muslim Relations 19, no. 2 (2008): 215-35.

44. Geaves, Ron. "Drawing on the past to transform the present: contemporary challenges for training and preparing British imams.” Journal of Muslim Minority Affairs 28, no. 1 (2008): 99-112.

45. Geaves, Ron. "The symbolic construction of the walls of Deoband.” Islam and Christian-Muslim Relations 23, no. 3 (2012): 315-28.

46. Darsh, Syed M. Questions and Answers about Islam. London: TaHa, 1997.

47. Kundnani, Arun. The End of Tolerance: Racism in 21st Century Britain. London: Pluto Press, 2007.

48. McGhee, Derek. The End of Multiculturalism? Terrorism, Integration and Human Rights. Maidenhead: Open University Press, 2008.

49. Bevir, Mark. “Governance and governmentality after neoliberalism.” Policy \& Politics 39, no. 4 (2011): 457-71. 
50. Birt, Yahya. “Governing Muslims after 9/11.” In Thinking Through Islamophobia: Global Perspectives. Edited by S. Sayyid and Abdoolkarim Vakil. New York: C Hurst \& Co., 2011, pp. 117-28.

51. Birt, Yahya. "Good imam, bad imam: civic religion and national integration in Britain post-9/11." Muslim World 96, no. 4 (2006): 687-705.

52. Brown, Katherine E. "The promise and perils of women's participation in UK mosques: the impact of securitization agendas on identity, gender and community.” British Journal of Politics and International Relations 10, no. 3 (2008): 472-91.

53. Sunier, Thijl. "Domesticating Islam: exploring academic knowledge production on Islam and Muslims in European societies.” Ethnic and Racial Studies, 2013, forthcoming.

54. Webb, Suhaib. "From protest to engagement." Presented at a Radical Middle Way event held at Westminster Central Hall, London, 24 February 2007.

55. Abd-Allah, Umar F. "Islamic extremism in the context of globalism." Presented at a Radical Middle Way event held at Birmingham Central Mosque, Birmingham, 18 November 2006.

56. Murad, Abdal-Hakim. Untitled talk presented at the launch of the Radical Middle Way, Kensington Town Hall, London, 6 December 2005.

57. Murad, Abdal-Hakim. "British and Muslim?” Masud, 17 September 1997. http://www.masud.co.uk/ISLAM/ahm/british.htm.

58. Murad, Abdal-Hakim. Muslim Songs of the British Isles: Arranged for Schools. London: Quilliam Press, 2005.

59. Hansard. "House of Commons daily debates." United Kingdom Parliament, 10 June 2009. http://www.publications.parliament.uk/pa/cm200809/cmhansrd/cm090610/halltext/90610h0004.htm.

60. David, Blanchflower. “The lost Muslim generation.” New Statesman, 15 February 2010.

(C) 2013 by the author; licensee MDPI, Basel, Switzerland. This article is an open access article distributed under the terms and conditions of the Creative Commons Attribution license (http://creativecommons.org/licenses/by/3.0/). 